(RETRACTION NOTICE)

\title{
Retraction Notice: Floating knee management
}

Lachkar Adnane *, Najib Abdeljaouad and Yacoubi Hicham

Department of orthopedic surgery B, University Hospital Center of Oujda - Morocco.

Publication history: Received on 19 September 2018; revised on 14 October 2019; accepted on 16 October 2019 Retracted on 20 February 2020.

DOI: https://doi.org/ 10.30574/wjarr.2020.5.2.0065

\section{Retraction notice}

Notice of formal retraction of review article 'Lachkar A, Najib A and Yacoubi H. (2019). Floating knee management. World Journal of Advanced Research and Reviews, 3(3), 41-46. (https://doi.org/10.30574/wjarr.2019.3.3.0065)' by Dr. Lachlar Adnane and his team members. This article has been retracted at the request of the Editors as a result of

(1) The Editors were recently alerted by a readers that in the manuscript almost word for word the text, some of the figures and almost the entire reference list is copied from the published article from journal EFORT Open Reviews: Muñoz Vives JM, Bel J-C, Capel Agundez A, Chana Rodriguez F, Palomo Traver J, Schultz-Larsen M, Tosounidis T. The floating knee: a review on ipsilateral femoral and tibial fractures. EFORT Open Rev. 2016; 1(11):375-82 (https://doi.org/10.1302/2058-5241.1.000042) and

(2) The inability of Dr. Lachlar Adnane and his team members to provide justifiable answer on this issue upon request of Editor in chief.

The Editors, after consultation with the Publisher and Editorial Board of the Journal, decided to retract the paper.

\footnotetext{
${ }^{*}$ Correspondance

E-mail address: editor @wjarr.com
} 